\title{
LIVING AND SOCIAL STANDARD OF POPULATION IN THE REGIONS OF THE CZECH REPUBLIC
}

\author{
J. Dufek, B. Minař́́k, V. Nepivodová
}

Received: March 8, 2011

\begin{abstract}
DUFEK, J., MINAŘÍK B., NEPIVODOVÁ, V.: Living and social standard of population in the regions of the Czech Republic. Acta univ. agric. et silvic. Mendel. Brun., 2011, LIX, No. 4, pp. 63-70

Living and social standard of the population of the regions of the Czech Republic has been assessed by means of six expert selected indicators. Characteristics of the levels and variability, correlation and regressive relations between the indicators were determined and the regions were divided into groups using cluster analysis. Based on the 4 main indicators selected by means of factor analysis, global scores of weighted standardised values of indicators of living and social standard of the population were calculated for the respective regions and the order of regions was established.
\end{abstract}

living and social standard of the population, development potential, order of regions of the Czech Republic

Following the interests of regional development as one of the fundamental objectives of the countries of the European Union, the Government of the Czech Republic adopted a plan named "Strategy of the Regional Development of the Czech Republic for the Years 2007-2013". To evaluate development potential of the regions descriptors were identified and within these, indicators were specified; this enables interregional comparison and subsequent decrease of the disparity of the regions. The complex assessment includes people, settlement, local economy, technical and transport infrastructure, landscape potential and environmental protection, use of culture potential, tourism, and public administration.

The essential descriptor here is the population of the regions evaluated from the point of view of its demographic development, living and social standards, employment, education, health condition, criminality etc.

The aim of this study is to evaluate the living and social standard of the population in different regions of the Czech Republic using certain indicators, to assess the disparity and to divide the regions into more homogenous groups which is then followed by ordering of the regions.

\section{MATERIAL AND METHODS}

The source data for the analysis were obtained from the website of the Czech Statistical Office. The total range of the indicators was evaluated according to their importance and weight using expert method, and six indicators were selected, out of which 3 indicators characterize the standard of living and 3 describe the social standard. The data used in this study refer to the year 2008 and have been converted to make them inter-regionally comparable.

When processing the numeric material the following statistical methods were used: calculation of the characteristics of the level and variability of the used indicators, their correlation and regressive analysis, cluster analysis for classification of the counties into more homogeneous groups, factor analysis for the selection of key indicators and point method for determining the order of the regions.

\section{RESULTS}

The Capital City of Prague shows significantly different values of all the indicators except for the number of recipients of incomes per 1000 population. GDP per capita in Prague is more than 
I: Source data of living and social standards of the population of the regions of the Czech Republic in 2008

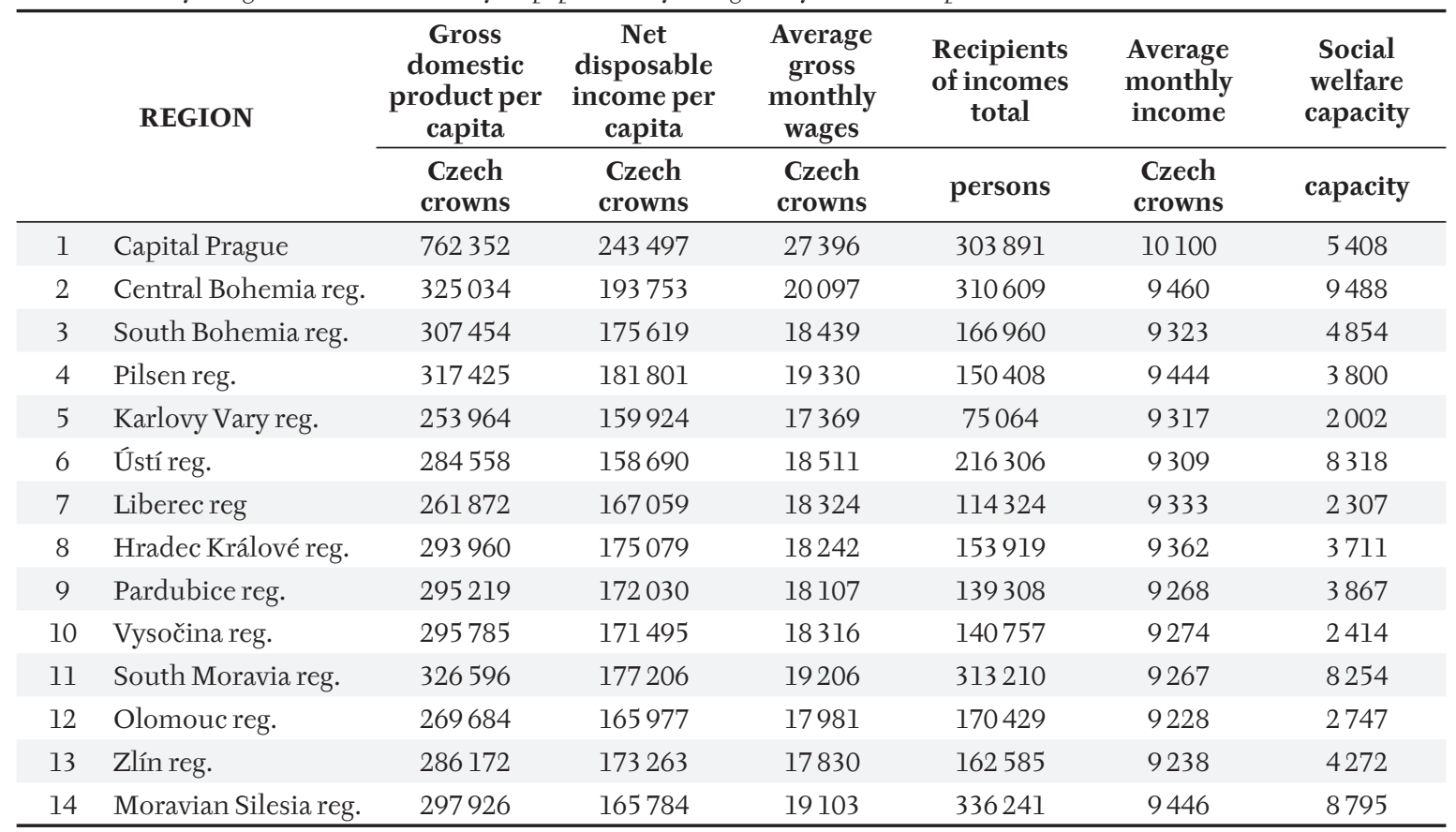

twice as high as in the other regions and average gross monthly wages is also far higher, although not too significantly.

The variation coefficient is the only suitable characteristic for mutual comparison. The highest variability is found at GDP per capita where the variation coefficient reaches $39 \%$.

An outline of the degree of the relations between the indicators of the living and social standards of the population of the regions of the Czech Republic is presented in the correlation matrix. If the data for the Capital of Prague are included, the rate of correlation is distorted due to the significantly different values of indicators, i.e. in most cases resulting in overestimation.

The highest degree of dependence is shown at researching the relation between the GDP per capita and average gross monthly wages; here the coefficient reaches very high values $\mathrm{r}=0.98$ $\left(\left(r^{2}=0,97\right)\right.$. This is greatly influenced by significant remoteness of the values for the Capital City of Prague.

Amore suitable way for the practical interpretation is the assessment of the relation without Prague

II: Characteristics of the level and variability in the regions of the Czech Republic in the year 2008 (or by December 31 ${ }^{\text {st }}$, 2008)

\begin{tabular}{lcccc}
\hline \multicolumn{1}{c}{ Indicator } & $\begin{array}{c}\text { Units of } \\
\text { measure }\end{array}$ & $\begin{array}{c}\text { Arithmetic } \\
\text { mean }\end{array}$ & $\begin{array}{c}\text { Standard } \\
\text { deviation }\end{array}$ & $\begin{array}{c}\text { Variation } \\
\text { coefficient }\end{array}$ \\
\hline GDP per l capita & crowns & 327000 & 127176 & 0.39 \\
NDI per capita & crowns & 177227 & 21072 & 0.12 \\
Average gross monthly wages & crowns & 19161 & 2472 & 0.13 \\
Recipients of incomes per 1000 population & persons & 263.73 & 10.52 & 0.04 \\
Average monthly income & crowns & 9384 & 220 & 0.02 \\
Capacity of welfare per 1000 population & capacity & 6.62 & 1.54 & 0.23 \\
\hline
\end{tabular}

III: Matrix for correlation coefficients for indicators of living and social standards of the regions of the Czech Republic

\begin{tabular}{rlccccc}
\hline \multicolumn{1}{c}{ Indicators } & $\mathbf{2}$ & $\mathbf{3}$ & $\mathbf{4}$ & $\mathbf{5}$ & $\mathbf{6}$ \\
\hline 1 & GDP per capita (crowns) & 0.95 & 0.98 & -0.42 & 0.95 & -0.36 \\
2 & NDI per capita (crowns) & - & 0.95 & -0.38 & 0.91 & -0.36 \\
3 & Average gross monthly wages (crowns) & & - & -0.46 & 0.97 & -0.33 \\
4 & Recipients of incomes per 1000 population (persons) & & & - & -0.53 & 0.06 \\
5 & Average monthly income (crowns) & & & - & -0.32 \\
6 & Capacity of welfare per 1000 population (vacancies) & & & & & - \\
\hline
\end{tabular}




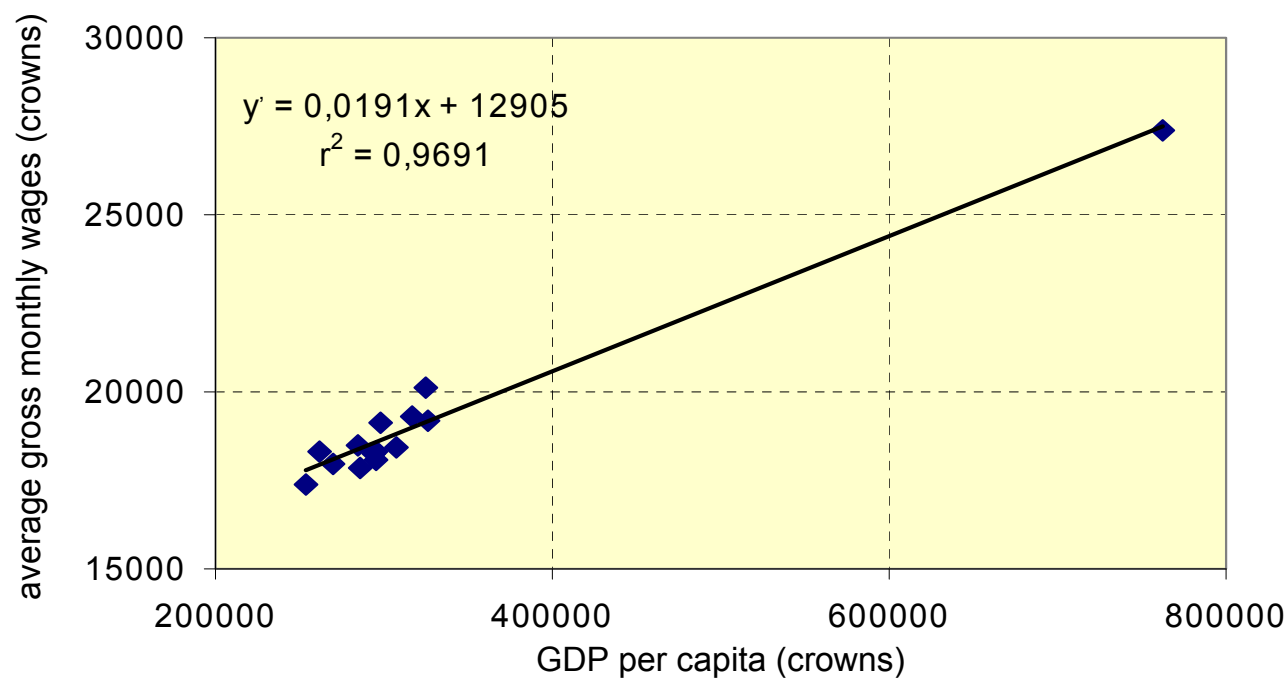

1: Relation between GDP percapita and average gross monthly wages within the set of all 14 regions of the Czech Republic

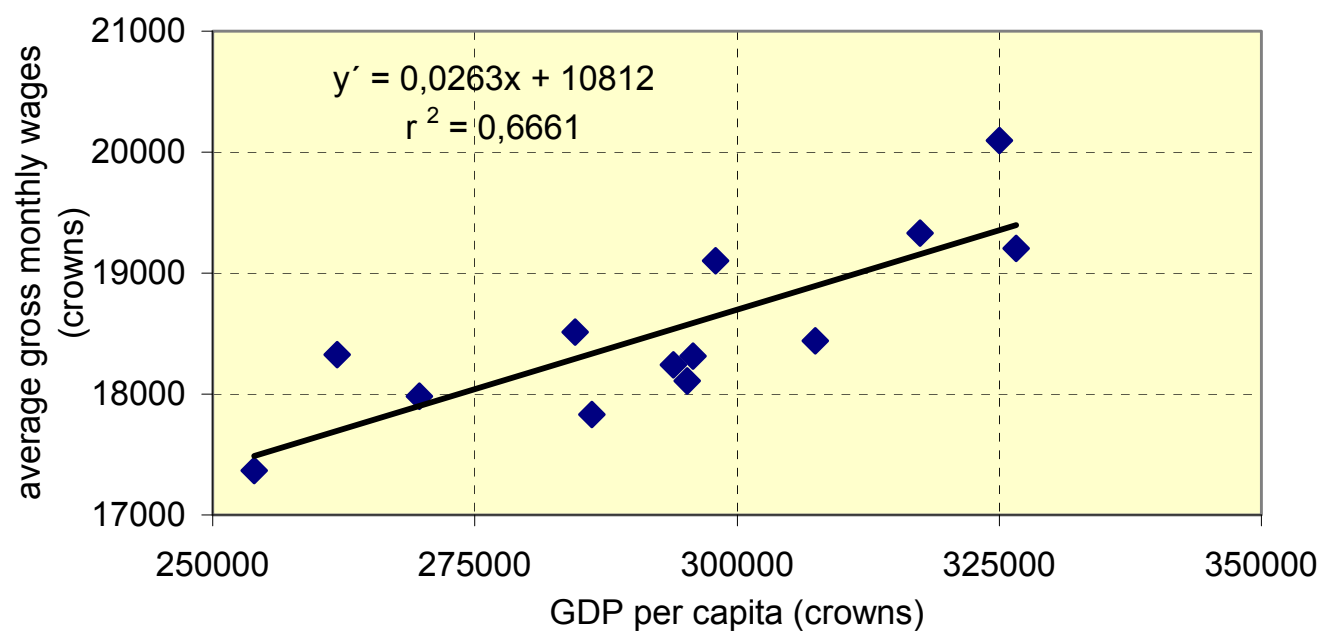

2: Relation between GDP per capita and average gross monthly wages within the set of 13 regions of the Czech Republic (Capital Prague excluded)

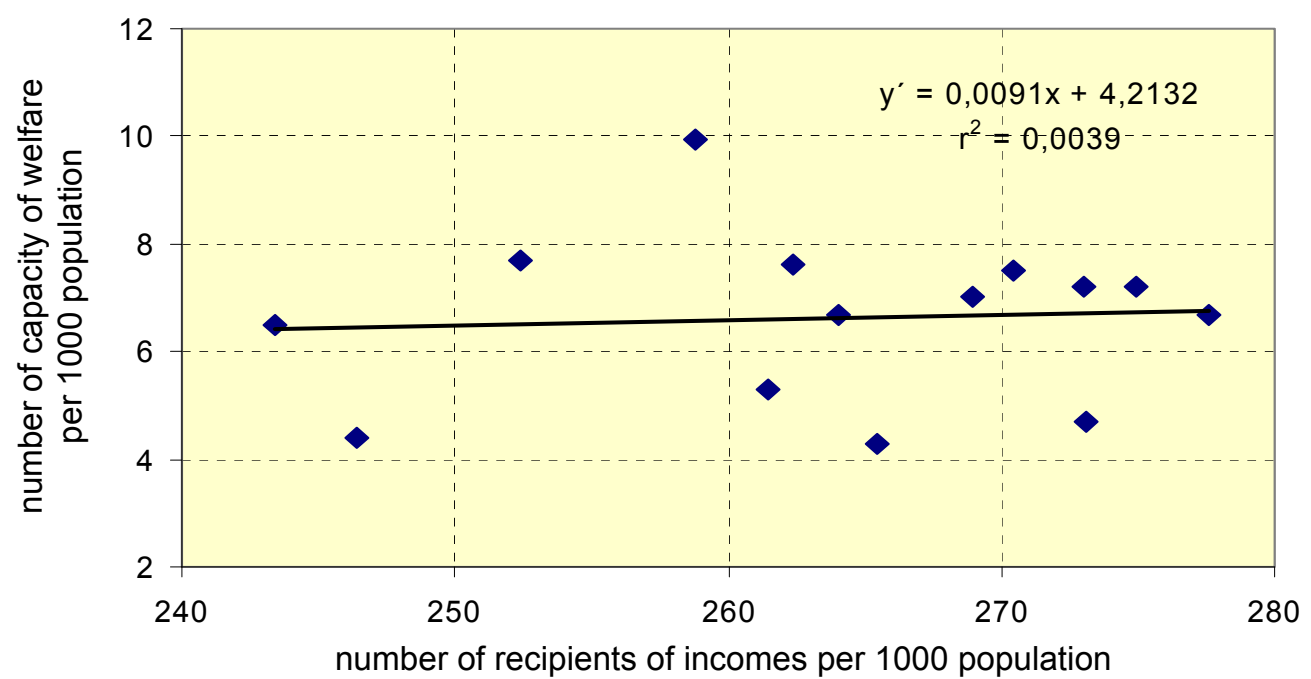

3: Relation between the number of recipients of incomes and capacity of welfare per 1000 population 
despite the fact that the degree of dependence is lower, where $r=0.82\left(r^{2}=0.6661\right)$. From the linear function we can infer that growth of the GDP per capita by 1000 crowns will bring the increase of the average gross monthly wages by 26 crowns.

On the other hand no relation has been proved between the number of recipients of incomes and capacity of welfare per 1000 inhabitants because $r=0.06\left(r^{2}=0.0039\right)$. In this case, the values of both the indicators for the Capital City of Prague do not deviate from the set of the regions of the Czech Republic, therefore it is not necessary to differentiate the set of regions with Prague included or excluded.

To divide the regions according to the living and social standards of the population cluster analysis has been used; all the values were converted into the

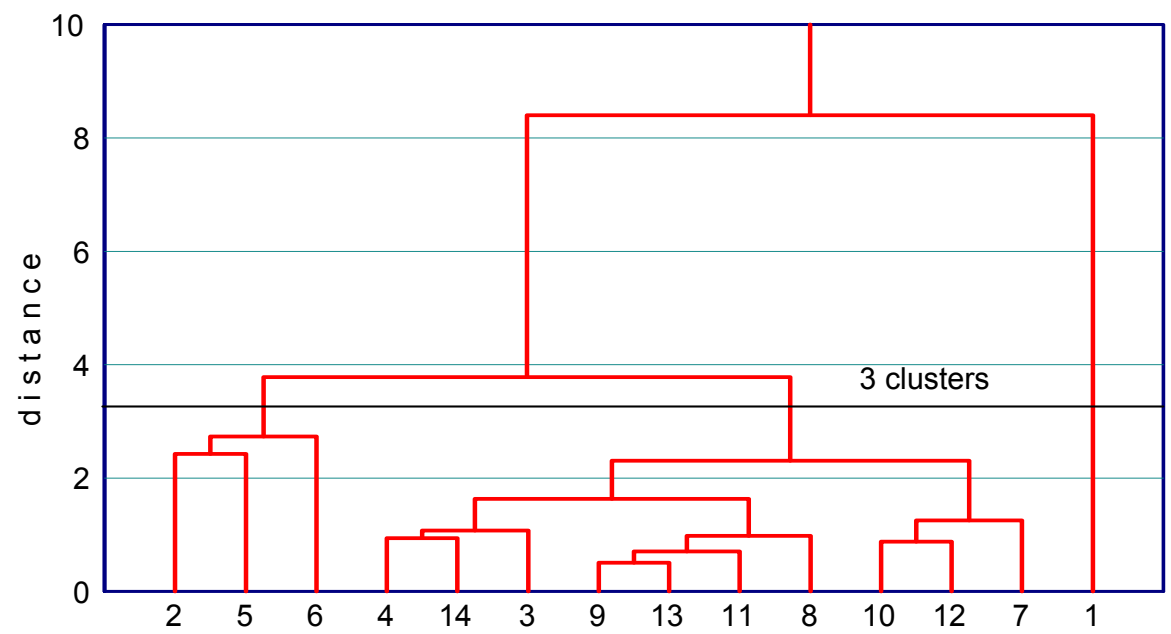

4: Dendrogram of regions of the Czech Republic according to all six selected indicators of living and social standards Formed groups of regions:

$1^{\text {st }}$ cluster: 1 region $(7.14 \%)$ :

$2^{\text {nd }}$ cluster: 3 regions (21.42\%):

1 - Capital City of Prague

$3^{\text {rd }}$ cluster: 10 regions (71.44\%):

2 - Central Bohemia reg., 5 - Karlovy Vary reg., 6 - Ústí reg.

3 - South Bohemia reg., 4 - Pilsen reg., 7 - Liberec reg., 8 - Hradec Králové reg., 9 - Pardubice reg.,

10 - Vysočina reg., 3 - Zlín, 14 - Moravia Silesia reg.

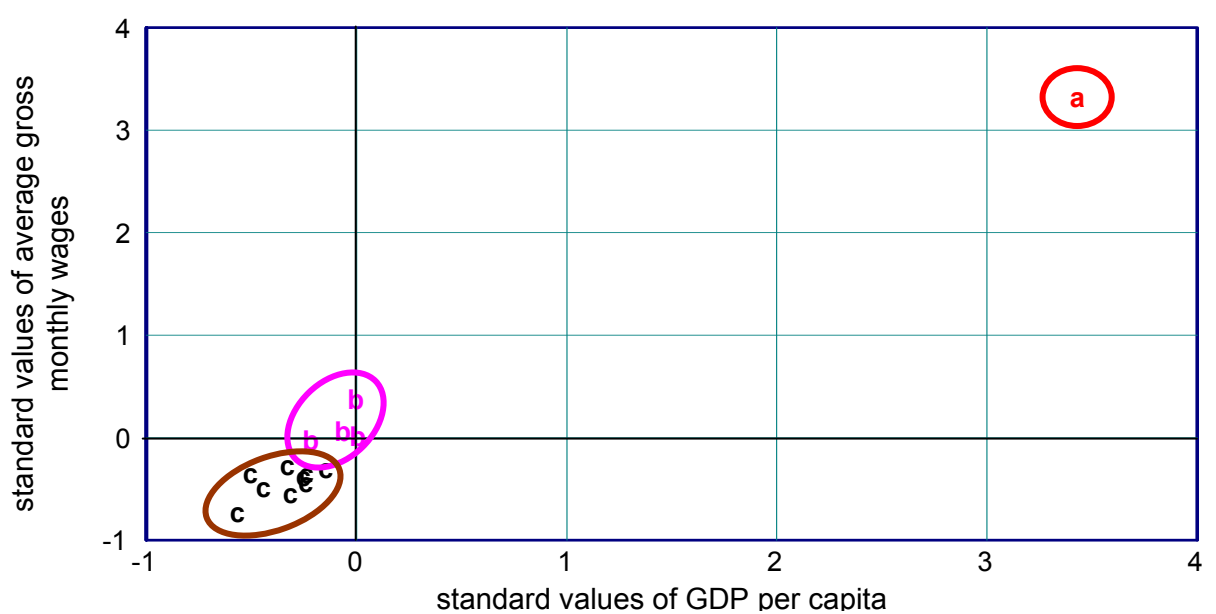

5: Dendrogram of the counties of the Czech Republic according to GDP per capita and average gross monthly wages Groups of regions:

a: far above-average GDP per capita and far above-average gross monthly wages

1 - Capital City of Prague

$b$ : average GDP per capita and average gross monthly wages

2 - Central Bohemia reg., 4 - Pilsen reg., 11 - South Moravia reg., 14 - Moravian Silesia reg.

c: $\quad$ slightly below-average GDP per capita and slightly below-average gross monthly wages

3 - South Bohemia reg., 5 - Karlovy Vary reg., 6 - Ústí reg., 7 - Liberec reg, 8 - Hradec Králové reg.,

9 - Pardubice reg., 10 - Vysočina reg., 12 - Olomouc reg., 13 - Zlín reg. 


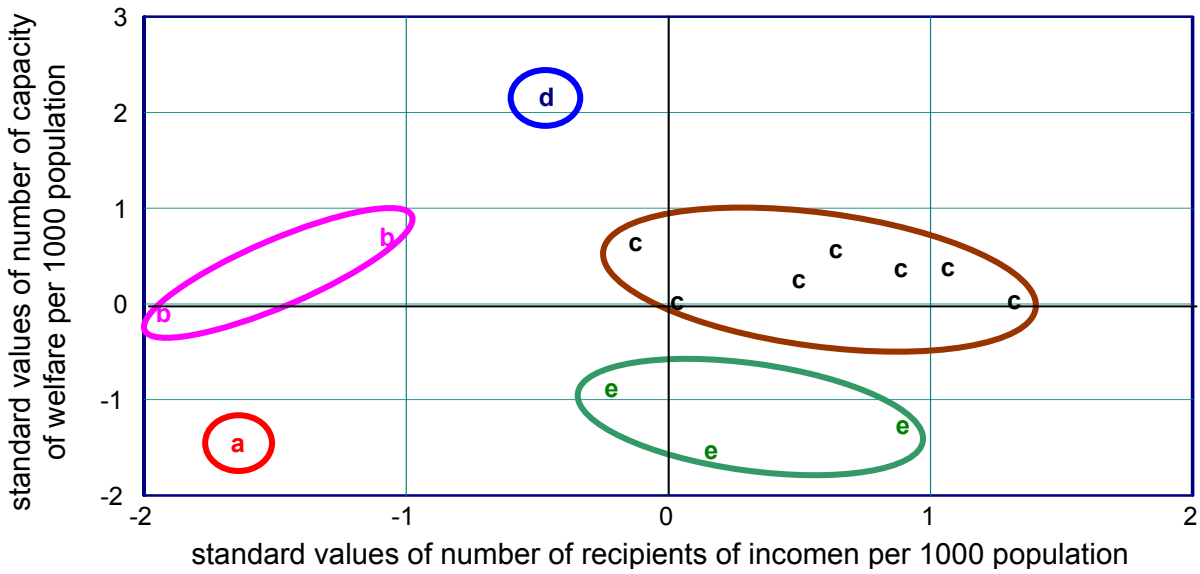

6: Chart of clusters of the regions of the Czech Republic according to the number of recipients of incomes and capacity of welfare per 1000 population

a: below-average number of recipients of incomes and below-average number of welfare capacity per 1000 population

1 - Capital City of Prague

$b$ : below-average number of recipients of incomes and average size of welfare capacity per 1000 population 2 - Central Bohemia reg., 5 - Karlovy Vary reg.

c: average to slightly above-average number of recipients of incomes and average size of welfare capacity per 1000 population

3 - South Bohemia reg., 4 - Pilsen reg., 8 - Hradec Králové reg., 9 - Pardubice reg., 11 - South Moravia reg., 13 - Zlín reg, 14 - Moravia Silesia reg.

$d$ : below-average number of recipients of incomes and above-average size of welfare capacity per 1000 population 6 - Ústí reg.

$e$ : average number of recipients of incomes and above-average number of welfare capacity per 1000 population 7 - Liberec reg., 10 - Vysočina reg., 12 - Olomouc reg.

standard variable of zero level and unit variability to avoid the impact of different units of measurement.

Grouping of the regions into three clusters is sufficient for the ordering of the regions according to all 6 selected indicators; one cluster represents the Capital City of Prague, another cluster contains three regions and all the other regions are included in the third cluster.

Two charts of clusters are drawn below to supplement the division of the regions according to the pairs of indicators.

To avoid duplication of the information and to pinpoint the main influences, the selection of the indicators for ranking of the regions from the point of view of the living and social standards has been done by means of factor analysis method. Eigenvalues higher than 1 have been obtained with two factors only but these have cumulated percent 73.8\% only. In order to get the cumulated percent exceeding $90 \%$, another two factors have been added resulting in cumulated percent reaching 95.8\%.

Analysis of the dispersion of factor analysis:

\begin{tabular}{cccc}
\hline Factor & Eigenvalue & Percent & $\begin{array}{c}\text { Cumulated } \\
\text { percent }\end{array}$ \\
\hline 1 & 3.06 & $51.0 \%$ & $51.0 \%$ \\
2 & 1.36 & $22.7 \%$ & $73.8 \%$ \\
3 & 0.90 & $15.1 \%$ & $88.8 \%$ \\
4 & 0.42 & $7.0 \%$ & $95.8 \%$ \\
\hline
\end{tabular}

Distribution of indicators into factors depending on the size of factor loads:

$1^{\text {st }}$ factor: average gross monthly wages (0.94), GDP per capita (0.90), NDI per capita (0.84)

$2^{\text {nd }}$ factor: recipients of incomes per 1000 population

$3^{\text {rd }}$ factor: $\quad$ welfare capacity per 1000 population

$4^{\text {th }}$ factor: average monthly income $(0.42)$

GDP per capita factor, which in the factor score ended second, was picked for the first position. This is because of its bigger importance as it significant for the average gross monthly wages, which stands in the first place.

Expert evaluation method was used with each indicator to get the weight and direction of operation. An overview of the weights and direction of operation is given in the chart:

\begin{tabular}{lcc}
\hline \multicolumn{1}{c}{ Indicator } & Weight & $\begin{array}{c}\text { Direction of } \\
\text { operation }\end{array}$ \\
\hline $\begin{array}{l}\text { GDP per capita (crowns) } \\
\text { Recipients of incomes per 1000 } \\
\text { population (persons) }\end{array}$ & 0.7 & positive \\
$\begin{array}{l}\text { Capacity of social welfare per } \\
\text { 1000 population }\end{array}$ & 0.8 & positive \\
Average monthly income (crowns) & 1.0 & positive \\
\hline
\end{tabular}


The order of the counties has been made on the basis of the total scores of weighted standardized values. Standardized values were multiplied by assigned weights to get the scores of the indicators. Positive indicators were added, negative indicators were subtracted and total score was made for respective counties across all indicators.

$$
\sum_{i=1}^{n} u_{i j} w_{i}
$$

where

$\mathrm{u}_{i j}$.......... value of the $\mathrm{i}$-th standard variable (indicator) in the j-th region (county), $w_{i}$........... weight of the i-th standard variable (indicator),

$u_{i j} w_{i} \ldots . . . .$. score of the $\mathrm{i}$-th standard variable (indicator) in the j-th region (county),

$n$............ number of variables (indicators).

According to the overall score, the first position is occupied by the Capital City of Prague (significant difference) followed by Central Bohemia reg. and Ústí region; the last positions belong to Olomouc reg. and Vysočina reg. The remaining counties located in the middle of the sequence show small differences.

IV: Partial and total scores of indicators of living and social standards in the regions of the Czech Republic from standard values and ranking of the regions for the year 2008

\begin{tabular}{|c|c|c|c|c|c|c|c|}
\hline & REGION & $\begin{array}{l}\text { GDP per } \\
\text { capita }\end{array}$ & $\begin{array}{l}\text { Recipients of } \\
\text { incomes per } \\
1000 \text { inhab. }\end{array}$ & $\begin{array}{c}\text { Capacity of } \\
\text { social welfare } \\
\text { per } 1000 \text { inhab. }\end{array}$ & $\begin{array}{l}\text { Average } \\
\text { monthly } \\
\text { income }\end{array}$ & Overall score & Order \\
\hline 1 & Capital Prague & 5.1348 & 1.1518 & -1.1585 & 3.2545 & 8.3826 & 1 \\
\hline 2 & Central Bohemia reg. & -0.0233 & 0.7545 & 0.5662 & 0.3455 & 1.6429 & 2 \\
\hline 3 & South Bohemia reg. & -0.2306 & 0.0898 & 0.5246 & -0.2773 & 0.1065 & 6 \\
\hline 4 & Pilsen reg. & -0.1130 & -0.0213 & 0.0260 & 0.2727 & 0.1644 & 4 \\
\hline 5 & Karlovy Vary reg. & -0.8615 & 1.3528 & -0.0675 & -0.3045 & 0.1193 & 5 \\
\hline 6 & Ústíreg. & -0.5006 & 0.3301 & 1.7298 & -0.3409 & 1.2184 & 3 \\
\hline 7 & Liberec reg. & -0.7682 & 0.1537 & -0.6961 & -0.2318 & -1.5424 & 11 \\
\hline 8 & Hradec Králové reg. & -0.3897 & -0.9209 & 0.0364 & -0.1000 & -1.3742 & 10 \\
\hline 9 & Pardubice reg. & -0.3749 & -0.4438 & 0.4623 & -0.5273 & -0.8837 & 9 \\
\hline 10 & Vysočina reg. & -0.3681 & -0.6235 & -1.0078 & -0.5000 & -2.4994 & 13 \\
\hline 11 & South Moravia reg. & -0.0048 & -0.6188 & 0.3013 & -0.5318 & -0.8541 & 8 \\
\hline 12 & Olomouc reg. & -0.6761 & -0.1118 & -1.2156 & -0.7091 & -2.7126 & 14 \\
\hline 13 & Zlín reg. & -0.4815 & -0.7439 & 0.3117 & -0.6636 & -1.5773 & 12 \\
\hline 14 & Mor. Silesia reg. & -0.3429 & -0.3466 & 0.2130 & 0.2818 & -0.1947 & 7 \\
\hline
\end{tabular}

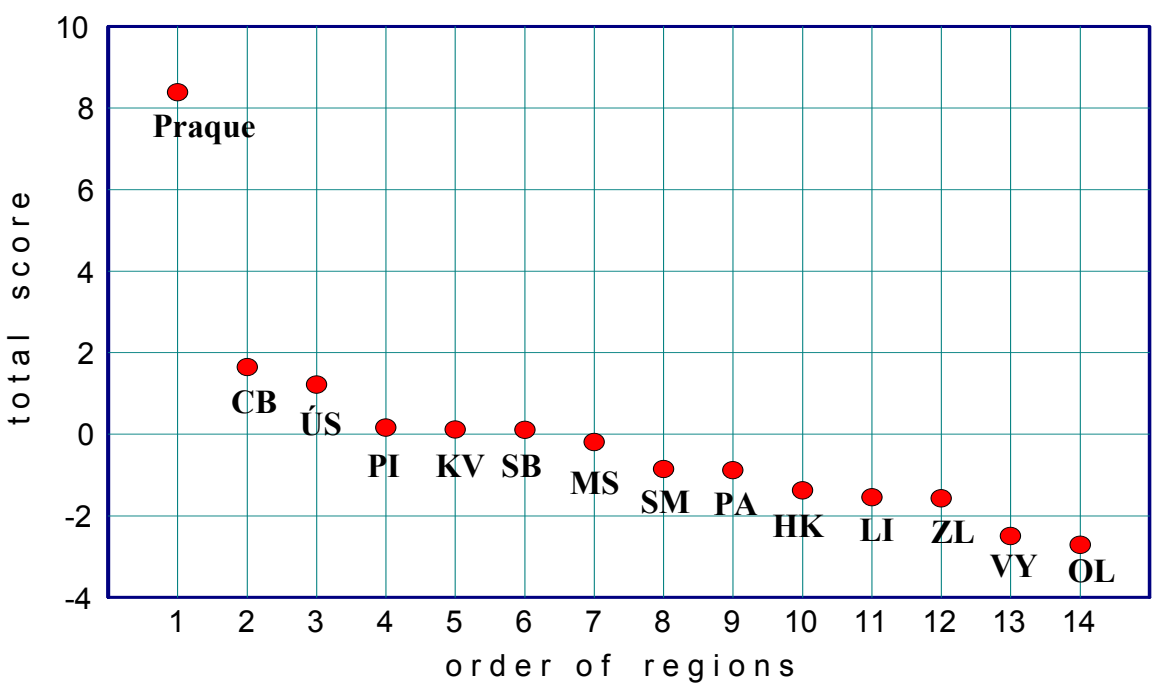

7: Order of the regions of the Czech Republic according to the total score of weighted standard values of living and social standards of the population in the year 2008 


\section{CONCLUSION}

The essential factor of the development of the society is people and this has been the topic of evaluation of the development potential of the regions of the Czech Republic from the point of view of human resources with quite a few authors namely Svatošová, Boháčková, and Hrabánková (2005), Svatošová (2006, 2007), Hrabánková (2007), Dufek (2008), Dufek and Minařík (2010).

This paper also deals with human resources from the point of view of their living and social standards. 6 indicators were used, characteristics of the level and variability were determined and the relationships were studied. The set of 14 regions of the Czech Republic was divided into more homogenous groups using the cluster analysis method followed by calculation of the total score of weighted standard values, and finally the order of the counties was established.

The results obtained through the survey offer a complex view of human resources in the respective regions. As such they might be useful in regional administration for inter-county comparisons, positive results may help improve the social and economic standards of the regions and they may provide a basis for measures to be taken to decrease disparities among the regions of the Czech Republic.

The paper was written within the framework of the research program MSM 6215648904 "Czech Economy in the Processes of Integration and Globalization, and Development of Agrarian Sector and the Sector of Services under the New Conditions of Integrated Agrarian Market", topical direction 5 "Social and Economic Relations of Sustainable and Multifunctional Agriculture and Measures of Agrarian and Regional Policies" and its partial project "Analysis of Demographic Development in the Czech Republic, Consequences of Delay in Comparison to the Developed Western Countries, Signs in the Rural Environment in the Basic Demographic Characteristics in General, and According to the Concrete and Specific Conditions of Czech Regions."

\section{SUMMARY}

Human resources play an important part in assessing the development potential of a region. It is obvious that higher living and social standards, economic activity, education, good health condition and overall optimal demographic development of a region are a prerequisite for the successful development of the region.

This paper deals with the assessment of one of the above aspects namely assessment of the living and social standards of the population of the regions. The object of the research is therefore the population of the regions of the Czech Republic; the relevant data refer to the year 2008. The main aim is the assessment of the reached level of inter-regional variability of human resources according to particular indicators, quantification of possible relations between the indicators, evaluation of the inter-regional differences, division of the regions into more homogenous groups and ranking of the regions. More or less the theme concerns assessment of development potential from the point of view of human resources.

The input data were obtained from the records of the Czech Statistical Office published on its web pages. The criteria for the selection of indicators of living and social standards were their significance and at the same time their availability for all the units of the assessed set of regions. 6 indicators were selected out of a greater number; 3 of them characterize living standard (GDP per capita, NDI per capita, average gross monthly wages) and another 3 describe the social standard (number of recipients of incomes, average monthly income, capacity of welfare).

The Capital City of Prague shows significantly different values with most indicators compared to the other regions and this has an impact on the calculated total numerical characteristics of the standard and variability, and it also influences quantification of the relations between the indicators and ranking of the regions into more homogenous groups. In order to determine groups of regions, the values of the indicators were converted into comparable dimensionless standardized variables and subsequently cluster analysis method was applied. Division into three groups appeared to be the best. In order to rank the regions from the point of view of the reached living and social standards, the number of indicators was narrowed to four, using the factor analysis method. Weight and direction of operation was determined by means of expert method; this determines whether the increase of the values of the indicators is a positive or a negative phenomenon. The order of the regions was then based on the total weighted score of the standard values.

The following can be inferred from the tables and charts: Prague occupies the first position followed by Central Bohemia reg. and Ustí reg., most of the counties with little differences are seen in the middle and the last positions are occupied by Olomouc reg. and Vysočina reg.

The results obtained through this research offer a rough overview of the development potential of the respective regions of the Czech Republic from the point of view of human resources. 


\section{REFERENCES}

DUFEK, J., 2008: Hodnocení krajů České republiky podle demografických charakteristik $\mathrm{V}$ roce 2006. Acta Universitatis Agriculturae et Silviculturae Mendelianae Brunensis, 3: 57-66. ISSN 1211-8516.

DUFEK, J., MINAŘÍK, B., 2010: Hodnocení rozvojového potenciálu kraju České republiky z hlediska lidských zdroji. Mendelova univerzita v Brně, Brno, $142 \mathrm{~s}$. ISBN 978-80-7375-424-2.

HRABÁNKOVÁ, M., 2007: Přístupy k řešení regionálních disparit ve venkovských oblastech. Libereckéekonomickéfórum 2007: 906-920.
SVATOŠOVÁ, L., 2006: Analýza potenciálu lidských zdrojů v regionech. Acta Universitatis Meridionales, The Scientific Journal for Economics, Management and Trade. 9: 71-74.

SVATOŠOVÁ, L., 2007: Lidské zdroje jako předpoklad regionálního rozvoje. Acta Universitatis Agriculturae et Silviculturae Mendelianae Brunensis, 3: 157-162. ISSN 1211-8516.

SVATOŠOVÁ,L.,BOHÁČKOVÁ,I.,HRABÁNKOVÁ, M, 2005: Regionální rozvoj z pozice strukturální politiky. České Budějovice: Jihočeská univerzita v Českých Budějovicích, Zemědělská fakulta, 173 s. ISBN 807040-749-2.

Address

prof. Ing. Jaroslav Dufek, DrSc., prof. Ing. Bohumil Minařík, CSc., Ústav demografie a aplikované statistiky, PhDr. Vlasta Nepivodová, Ústav jazykových a kulturních studií, Mendelova univerzita v Brně, Zemědělská 1 , 61300 Brno, Česká republika, e-mail:dufek@mendelu.cz, minarik@mendelu.cz, nepivodo@mendelu.cz 